\title{
IAMJ
}

INTERNATIONAL

AYURVEDIC

MEDICAL JOURNAL

\section{DRUG REVIEW OF KUSHAMOOLA CHURNA WITH TANDULODOK IN ASRUGDARA MANAGEMENT}

\author{
Aarifa Shaikh ${ }^{1}$, Umesh Lunawat ${ }^{2}$ \\ ${ }^{1}$ M.S. Striroga \& Prasuti Tantra \\ (Associate Professor- Dept of Striroga \& Prasuti Tantra) at SGR Ayurved College, Solapur, Maharashtra, India \\ ${ }^{2} \mathrm{HOD} \&$ Associate Professor, Jupiter Ayurved College, Nagpur, Maharashtra, India
}

Corresponding Author: aarifashaikh2685@gmail.com

\section{https://doi.org/10.46607/iamj4209102021}

(Published Online: October 2021)

Open Access

(C) International Ayurvedic Medical Journal, India 2021

Article Received: 06/10//2021 - Peer Reviewed: 18/10/2021 - Accepted for Publication: 19/10/2021

\section{Check for updates}

\begin{abstract}
In Ayurveda, menstruation has been described in 3 phases as rajahkala (menstrual period) rutukala (fertile period) and rutuvyatitkal (premenstrual period) \& Do's and Don'ts regarding this has also been explained in detail. Due to so much physical and emotional stress women are suffering from so many menstrual problems, Asrugdara (menorrhagia) is one of them and in Samhitas its causes, Etiopathogenesis, treatment and complications are explained in detail. Menorrhagia is being treated with hormonal combination have so many side effects in acute as well as chronic therapy.

Kushamool churna with tandulodak (Rice water) as explained by Bhaishajya Ratnawali treats Asrugdara in 3 days. Due to its pharmacological properties, it breaks down the pathology of Asrugdara in the acute stage. So, we can formulate this combination for the acute condition of menorrhagia.
\end{abstract}

Keywords: Rajahkala, Rutukala, Rutuvyatitkal, Asrugdara, Menorrhagia, Etiopathogenesis.

\section{INTRODUCTION}

Ayurveda, like every science, has its own philosophy and its own way of approach. Clinical research is the most fruitful line of approach to evaluate the methods of diagnosis and treatment. 
${ }^{1}$ Acharya Charak said that the best Physician knows the science of drug administration according to 'Desha' i.e., patient's body and 'Kala' (time). He prescribes a drug only after examining each patient individually. A clinical study requires very keen observation of patients as well as the effect of a drug to prove any hypothesis in the field of research.

As in nature, the regularity of seasons denotes its normal way in the same manner, a regular menstrual cycle indicates the normal wellbeing of a woman. Asrugdara ${ }^{2}$ (menorrhagia) is one of the main menstrual disorders in women. Because of disturbance in intake of proper diet, rest, stress, multiple miscarriages and abortions, menstrual disorders have become common in women nowadays. Management of such disorders by hormones often causes undesirable side effects. Several medications with hormonious principles have been described in Ayurvedic classics.

The term 'drug' is derived from the French word 'Drogue' means a day herb/product that is used to modify or explore the pathological/physiological status for the benefit of the recipient.

${ }^{3}$ Since oldest literature i.e., Veda glorifies that drug were worshipped as God and Samhitas also explain that "Nothing in the world exists without any thera- peutic utility". Taking this fact into consideration. Ayurvedic physicians have formulated single as well as compound drugs for the cure and prevention of various ailments.

\section{DISCUSSION}

${ }^{4}$ In Asrugdara so many preparations of shodhan (purification) and shaman (suppression) have been mentioned. All these medications in shaman chikitsa have certain common fundamental properties i.e., pitta, vata shamak, kapha shodhak, Raktashodhak (Purification of blood) Stambhak (Astriction), Garbhashay balya (Uterine tonic) \& vatanulomak (Down forcing Vaat). In Ayurveda, a protocol for Asrugadara management is Agnideepan (Ignition of Agni), Raktasangrahan (Coagulation of blood) with dosha pachan (Desiccation).

${ }^{5}$ Bhaishajya Ratravali being ancient literature about drugs and diseases mentioned that the drug Kushamoolachurna along with tandoolodak can cure Asrugdara in 3 days

Kushamoola (Desmostachya Bipinnata)

Tandool (Oryza Sativa) i.e., rice

In Ayurveda, drug action depends on Rasa, guna, virya, vipak.

Table 1: Pharmacological properties of the drug

\begin{tabular}{|l|l|l|}
\hline & ${ }^{6}$ Kushamool & ${ }^{7}$ Tandool \\
\hline Rasa (Taste) & madhur, kashay & madhur, kashay (Astringent) \\
\hline Virya (Potency) & Sheeta (Cool) & sheeta \\
\hline Vipak (After digestion taste) & Madhur (Sweet) & Madhur \\
\hline Guna (Qualities) & Snigdha, laghu & Laghu, snigdha (Smooth) \\
\hline Form & Churna (Powder) & Rice water $($ Hima) \\
\hline Latin Name & Desmostachya Bipinnata & Oryza Sativa \\
\hline Doshaghnata (Dosha regulation) & Tridoshaghna & Tridoshaghna \\
\hline
\end{tabular}

${ }^{8}$ Tandoolodak is rice water made by 1 part of rice and 6 parts of water-soaked overnight as explained by Acharya Sharanghar in Himakalpana. 


\begin{tabular}{|c|c|}
\hline $\begin{array}{l}9 \text { Samprapti (etiopathogenesis) of Asrugdara } \\
\text { Nidana sevan } \\
\text { (Intake of causative factor) } \\
\downarrow \\
\text { tridosha prakopa } \\
\text { (Aggravation) } \\
\downarrow \\
\text { Agnimandya } \\
\text { (Dyspepsia) } \\
\downarrow \\
\text { Vikrut ahar rasa } \\
\text { (Defective) } \\
\downarrow \\
\text { rasagni vaishamya } \\
\text { (Inequality) } \\
\downarrow \\
\text { vikrut rasadhatu } \\
\quad \downarrow \\
\text { Artava Updhatu } \quad \downarrow \\
\text { (Subtissue) } \\
\downarrow \\
\downarrow \\
\downarrow \\
\downarrow \\
\downarrow \\
\text { affect uterine vascular apparatus } \\
\text { Apan Vayu dushti } \\
\text { (Vitiation) } \\
\downarrow \\
\text { Asrugdara }\end{array}$ & $\begin{array}{l}\text { Probable Action of Kashamoola churna with tandulodak } \\
\downarrow \\
\text { Pitta shaman \& vatanuloman } \\
\downarrow \\
\text { Kashay rasa- agnideepak } \\
\downarrow \\
\text { Agnideepan } \\
\downarrow \\
\text { Doshpachan } \\
\downarrow \\
\text { Raktastambhan \& raktasangrahan by sheet virya } \\
\downarrow \\
\text { Breaks actual pathogenesis } \\
\downarrow \\
\text { bleeding stops by rakta sangrahan \& stambhan } \\
\downarrow \\
\text { Daurbalya (Weakness)\& Panduta (Pallor) cured by madhur } \\
\text { and snigdha guna } \\
\downarrow \\
\text { breaks down the last phase of pathogenesis }\end{array}$ \\
\hline
\end{tabular}

III) Chemical Properties:

Table 2: Chemical Composition
${ }^{10}$ Kushamool
Eseroline - anti cholinergic, analgesic
Camphene- antioxidant
Caryophyllene- anti-inflammatory
Eudesmol-hepato protective

\section{${ }^{11}$ Tandool}

Vitamin $\mathrm{B}, \mathrm{B}_{2}, \mathrm{~B}_{3}, \mathrm{~B}_{5}, \mathrm{~B}_{6}$ along with carbohydrates, sugar, fibres and protein.

\section{CONCLUSION}

So, it can be concluded that Kushamoola churna along with tandoolodak proves to be effective in Asrugdara. Ayurvedic classics have been mentioned this far ago so clinical trials should be carried out for efficacy evaluations of such formulations, for better treatment of diseases and to minimize surgical interventions.

\section{REFERENCES}

1. Dr. Y.G. Joshi/ Kayachikitsa / Chapter 1/ Sampada Kopardekar publication / Pune/ 2017/ pg. 15

2. D.C. Dutta/ Textbook of Gynaecology/ Menstrual Disorder/New Central Book Agency/ Kolkata/ Fourth Edition/ 2004/pg. 175.

3. Dr. Y.G. Joshi/ Kayachikitsa / Chapter 1/ Sampada Kopardekar publication / Pune/ 2017/ pg. 15

4. Prof. Premvati Tewari/ Ayurvediya Prasutitantra Evam Striroga- Part II/ Artava Vyapada prakaran/ Chaukhambha Orientalia Publication/ Varanasi/ Second Edition / 2016/ pg. 196. 
5. Govinddas / Bhaishajya Ratnavali/ Strirogadhikar / Motilal Banarasidas Publication/ Delhi/ 2007/ pg. 698.

6. Prof. P.V. Sharma/ Dravyaguna Vijnana Vol. II/ Chaukhambha Bharti Academy/ Varanasi/ 2018/ pg. 634, 635.

7. Shri. Bappalal Vaidya / Nighantu Adarsha Part- II/ Chaukhambha Bharti Academy/ Varanasi/ 2016/ pg. 758.

8. Vidyasagar Shastri/ Sharangdhar Samhita-Addhamalla tika/ Chapter No. 4/ Chaukhambha Surbharti Publication/ Varanasi/2018/pg. 172.

9. Prof. Premvati Tewari/ Ayurvediya Prasutitantra Evam Striroga- Part II/ Artava Vyapada prakaran/ Chaukhambha Orientalia Publication/ Varanasi/ Second Edition / 2016/pg. 174.

10. www.tandfonline.com / 2.10.2021 at $12.33 \mathrm{pm}$.

11. www.sciencedirect.com / 2.10.2021 at 2.45 pm.

\section{Source of Support: Nil}

\section{Conflict of Interest: None Declared}

How to cite this URL: Aarifa Shaikh o $\mathcal{L}$ Umesh Lunawat: Drug Review of Kushamoola Churna With Tandulodok In Asrug-Dara Management. International Ayurvedic Medical Journal \{online\} 2021 \{cited October 2021\} Available from: http://www.iamj.in/posts/images/upload/2550_2553.pdf 